\title{
Kindergarten Teachers' Beliefs and Attitudes about Developmentally Appropriate Art Practice in Taiwan
}

\author{
Pi-Hui Lai
}

\section{Introduction}

Early childhood education in Taiwan presents a variety of curriculum emphases. Because of the extreme emphasis on academic achievement in Taiwan, the art curriculum is often sacrificed. Even in kindergartens, most of the time is often devoted to teach academic subjects such as Chinese phonetic symbols or numbers. As a result, the time available for an art activity is reduced.

Developmentally appropriate practice (DAP), which has been widely adopted by American early childhood programs, is still new to the Taiwanese educators. It could be an answer for offering a better quality art education to children in Taiwan. The purpose of this study is to understand teachers' attitudes toward developmentally appreciate art practice. Knowledge from this study can help educators and administers to understand what efforts should be made when applying this practice in early childhood classrooms, and offer children in Taiwan a better quality art learning environment and curriculum.

\section{Research Questions}

Question 1: What art teaching approach do Taiwanese kindergarten teachers adopt?

Question 2: In the teachers' viewpoints, what is the purpose of kindergarten art education?

Question 3: What are teachers' attitudes toward DAP art education?

Question 4: What modifications can be made to meet teachers' needs when carrying out DAP art practice?

\section{Literature Review}

\section{Concepts of Developmentally Appropriate Practice}

According to the position statement of National Association for the Education of Young Children (Bredekamp and Copple, 1998), DAP is: 1. What is known about child development and learning - knowledge of age-related human characteristics that permits general predications within an age range about what activities, materials, interactions or experiences will be safe, healthy, interesting, achievable and also challenging to children; 2. What is known about the strengths, interests, and needs of each individual child in the group to be able to adapt for and be responsive to inevitable individual variations; and 3 . Knowledge of the social and cultural contexts in which children live to ensure that learning experiences are meaningful, relevant, and respectful for the participating children and their families. (p.9) It mainly adopts Piaget's (1952) cognitivedevelopmental theory and Vygotsky's (1978) sociocultural theory.

\section{Concepts of Early Childhood Art Education}


Children's Art Development: Lowenfeld and Brittain (1987) offer a linear explanation of children's art development. They analyze children's art development and put it into five stages--scribbling stage, preschematic stage, schematic stage, gang stage, and adolescent art stage--which have been influential to art education for several decades. Davis (1997) offers an alternative view of children's art development, based on the results from Harvard Project Zero she considered children's art development more Ushaped or L-shaped in nature. In other words, children reach their peak of imagination and creativity at a very young age and later, their imagination and creativity gradually decline as they increase in age. For most people, the art development is more of an Lshaped process, however, for some gifted children and talented artists, their art development follows more of a U-shaped curve. As for the three dimensional medium, Golomb (1997) observed young children working with clay and categorized children's construction style into two strategies - addition and subtraction. She concluded the majority of children use the addition strategy to work with clay, and children as young as five years old have developed a basic understanding of three-dimensionality. In addition, complexity, symmetry and balance of the clay object were the three elements that influenced children's clay modeling significantly.

Value of Children's Art: Art serves as a natural vehicle for young children to present their creative ideas and express their inner feelings (Lowenfeld \& Brittain, 1987). During the art making process, young children also apply their problem solving skills and motor skills to make their ideas come to life on paper; this allows the children to understand themselves better. Moreover, children use social and language skills when they interact with peers and teachers while making art. In fact, every developmental domain of the child--cognitive, physical, language, social, and emotional development--is encouraged by the art activity (Lasky \& Mukerji-Bergeson, 1995).

Children's Art Making Processes: Based on Beittel's $(1972,1973)$ three essential conditions for making art--artistic causality, idiosyncratic meaning and intentional symbolization--Zurmuehlen (1990) offers an interpretational theory for the art making process-art as praxis, art as symbol and art as presence. When making art, the artist is an originator. In other words, he/she is not a "pawn" (Zurmuehlen, 1990, p.18). By following the praxis of his/her previous life experiences, the artist gets the idea to make his/her own unique artwork. He/She is not merely doing something with the art materials, but he/she turns doing into making. There is a reflective dialogue between the artist's inner world and the art making action, which guides the artist's creation. The artwork is the representation of the artist himself/herself. "I am what I do" or "I am what I make" (Zurmuehlen, 1990, p.18) explains the notion of artistic causality, which closely relates to the artist's life praxis as well.

In addition, the artist is a transformer in the art making process. He/She symbolically transfers his/her personal experiences and thoughts through the art making process into his/her artwork. In other words, the artist's mind, which takes in various daily experiences from the outside world, is the source of his/her creation. In this symbol-making process, the images the artist makes have some special meaning attached to them. His/Her artwork is unique and calls for the viewers' attention to the phenomenal presence that the artist has experienced.

Finally, the artist is a reclaimer. In the art making process, the artist "works over into the art materials some equivalent of his/her idiosyncratic meaning, to use the 
properties of the medium for personal relevance." (Zurmuehlen, 1990, p.28) That is, the artist intentionally reclaims the phenomenal presence gained from his/her life experiences by using the art materials to put the images and ideas from inside his/her mind into his/her artwork. This final concept is viewed as a synthesis of the previous two concepts (Zurmuehlen, 1990). Like adult artists, even young children show these essential conditions when making art.

"First the making and then the naming" (p.1) is Zurmuehlen's (1990) other philosophy for explaining art making. Many times when making art, we do not consciously intend to make anything. It is like when a teacher assigns an activity and we simply follow the teacher's instructions and do it. In such cases, there is no conscious intention originating from within us to make the art. However, when there is reflective dialogue happening between ourselves and our artwork about how and what the artwork should be, then doing art subtly becomes making art. The difference of making art and doing art is the action of "intended" doing with the art materials. Thunder-McGuire (1994) shows that children, too, have this "inner critic" (p. 51) or reflective dialogue between themselves and their artwork as they make art. This inner critic guides children to work with art materials and purposefully transfer the art doing into the art making. They are more than art material manipulators, but instead become meaning makers (Thunder-McGuire, 1994). Then, after a meaningful art-making process, the children tend to name their artwork, with or without adult prompting.

Moreover, Zurmuehlen and Kantner (1995) pointed out that "boundedness" (p.8) and "repetition" (P.8) are two important elements of the children's art making process. In preschooler's early drawings, we often find that there is a kind of repetition in the children's art making process. The themes in young children's artwork also show that the presence of repetition dominates their pictures. Duncum (1997) points out that several recent studies have revealed that children like to draw the same topic over and over again.

Developmentally Appropriate Art Education: A nonintervention approach supported by Kellogg (1970) and Lowenfeld and Brittain (1987) has been widely used for teaching young children about art for the past several decades (Kindler, 1995, Thompson, 1995). It views children's art-making as a naturally unfolding process. This approach states that adult intervention while children making art is unnecessary. However, Thompson (1995) and Kindler (1995) suggested that this kind of self-instruction approach is appropriate for very young children only, and that adults' contributions to young children's art development is essential. DAP art practice is another child-centered approach and also emphasizes the importance of adult input in young children's art learning. In this practice, teachers play the role of facilitator, evaluator, communicator, interactor and decision-maker in order to help children to achieve Vygotsky's "zone of proximal development" (Vygotsky, 1978, p. 84).

\section{Methodology}

The design of this study is qualitative in nature. The research setting was in the kindergarten classrooms in the northern part of Taiwan. Fourteen teachers were invited to participate in this study. The research procedure can be divided into two phases: 1 . Observations and 2. Interviews. Fieldnotes were jotted down during the observations and interview contents were tape recorded. 
Three open questions related DAP art practice were asked after the observations: 1. What is the purpose of art education for kindergartners? 2. Theoretically, there are three kinds of approaches for teaching young children art in the classroom. Which method do you like or prefer? Which method do you think you are using right now in your classroom? 3. What kind of changes do you think kindergarten art education in Taiwan will need in the future?

Interpretation was derived from carefully comparing and contrasting the obtained data. Like all qualitative studies, the results can not be used to make generalization for all kindergarten teachers in Taiwan.

\section{Findings and Results}

\section{The Purpose of Kindergarten Art Education-Idealistic or Realistic}

For most kindergarten teachers in Taiwan, there was not a big difference in ideals regarding kindergarten art education, despite the type of school or the location of the school. According to the professionals I interviewed, art activities can provide many benefits to young children. They stated that art can help young children build their small muscles, develop their creativity and thinking skills, offer opportunities for manipulation, learn to appreciąte beauty, gain a hobby, express feelings, gain patience, train observational abilities, learn about socialization, acquire knowledge, gain better hand-eye coordination, improve mathematical-logical concepts, and learn art skills. Some public kindergarten teachers, like Mrs. Hu and Mrs. Chang, even believed that art could help children learn the proper pen holding position for writing in the elementary school. Many emphasized the importance of art appreciation and creativity. As Mrs. Chen, a public kindergarten teacher, indicated, "Personally, I think the importance of kindergarten art education is in learning to appreciate art. Allowing children to see art and participate in art will help them to cultivate their own appreciation of art." $\mathrm{Mrs}$. $\mathrm{Hu}$, a public kindergarten teacher, stated, "I think the purpose (of art) for the kindergarteners is to allow them to create freely. That is, allow children to develop creative thinking--this ability rather than a product."

However, one private kindergarten teacher, Mrs. Hsu, stated that the purpose of kindergarten art education has changed recently. Learning better art skills and becoming more talented has become more important than the reasons mentioned before. It also reflects a current popular trend in private kindergartens - the art talent class. She indicated:

However, it seems that now the purpose of kindergarten art education has become for children to learn art skills. Ha! Ha! Ha! Everyone seems to use art as a kind of progress. Even the elementary schools offer a gifted art class, music class or choir class, so now when parents send their children to learn art, they tend to hope they will become more artistic, not because they want to fully develop their creativity.

Currently, no public kindergartens offer art talent classes because of government regulations. Most public kindergarten teachers indicated that they would not support such an art class for their children even if they could set one up. One public kindergarten teacher as well as principal, Mrs. Chen, mentioned that it depends on why the parents request that their children attend such a school. Do the parents send their children only 
for fun, or do they ask their children to achieve some level of art skill after they have attended? If it is the latter, both the teachers and the children will feel pressured to please the parents, since they request that their children gain better art skills. She said, "... If the parents' goal in having their child attend these classes is to allow their child to obtain a certain art skill in a specified time, then I would not like to have this kind of art class (in my school)."

In addition, Mrs. Lin, a public kindergarten teacher as well as a principal, stated that this kind of art talent class cannot adapt to the current curriculum changes of the kindergartens. Currently, most public kindergartens adopt thematic units to design the curriculum, which incorporates various fields of knowledge together instead of dividing them into different subjects. The special art class cannot meet these current curriculum needs because it is separate and does not connect to other curriculum areas. Moreover, she considered that this type of kindergarten art education was a kind of restricted learning. In other words, she thought the teachers' control and instruction would limit the children's creation. A private kindergarten principal as well as a teacher, Mrs. Tsai, just discontinued such an art talent class for this reason. Both of them believed it restricted learning because of the teaching approach adopted by the art specialists. Mrs. Tsai stated:

I don't like this 'frame', because for five years we used this 'frame' to educate our children. I felt this way, and some parents thought the same thing. They said, 'The children's products are all the same!' The children's creation was limited, even though they felt they had more of a sense of fulfillment. Parents who have education said they do not want this kind of fulfillment. They said they do not need this kind of product to be put in front of them, because it would become garbage in the future.

Mrs. Lin and Mrs. Tsao also pointed out that children's creativity would be totally stifled if the teacher makes artwork for the children or modifies the children's work. It is true that the teacher-aided artwork can please parents, since parents prefer to see results. As Mrs. Lin, a public kindergarten teacher as well as a principal, stated, "Basically, they (parents) think the art classes can teach art better. ... So, they hope their children can go to special classes and learn special skills. Then, it is much easier for them to see results."

The product, as Mrs. Lin mentioned, could entice more parents to send their children to the art talent class. However, these are artificial achievements. Children's ideas for creating freely are limited or even extinguished. These elements influence public kindergarten principals' decisions about setting up an art talent class in their schools.

Even though there are many concerns about this issue, one public kindergarten teacher and principal, Mrs. Chang, does feel the need to open the door to such an art class. She considered it a responsibility of the school to offer opportunities for young children who do not have a chance to learn art. She said:

I think as a teacher I am responsible to provide children with such an art class. It opens the doors of learning for them. For example, if they have never had physical education class before, they will not know that it is a fun class. If we do not have this class, then the door for the children is closed. Children have no way to know what the physical class is about, or the English class is about, or the computer class is about. So when I offer a clay class, it opens the door for 
children, and then they have the opportunity to learn. If they want to study it more later, they can. However, each teacher should be responsible and offer many classes.

Some principals and teachers believed that private kindergartens were just finding ways to get more money from the parents. Mrs. Lin, a public kindergarten teacher and principal, stated:

As for why the private kindergartens like to set up such art classes within their schools, in fact, they are for the purpose of making money. Because right now both parents work outside the home, and if their children stay in kindergarten all day, what can they do? They are just trying to find another reason to ask for extra money from the parents. The kindergartens offer an art class and then they ask the children if they want to take this class or not. And if they also provide music class or another class, then they can get some extra money. In fact, all children's time is spent in kindergarten.

Parents in Taiwan have various reasons for sending their kindergarten children to such an art talent class. In some schools, it is not a choice, since the art talent class is offered to every child in the kindergarten. So, if the parents choose this kindergarten for their children, it also means they will have to attend the art class provided during regular school hours. Some extra fees may be charged. Perhaps because of competition among private kindergartens, they feel they need to offer such art talent classes to attract parents. Another reason could be that the private kindergartens need to prolong the school hours to meet the parent's needs, so they provide such after school programs.

Many kindergarten teachers indicated in the interviews that parents hope that their own children will be better than other children. This desire to make comparisons between their own children and other children makes this kind of art talent class popular in Taiwan. Every parent hopes that his or her child can be very talented and learn more, without considering what the child wants. Some teachers and principals said it was a kind of vanity for the parents. Mrs. $\mathrm{Hu}$, a public kindergarten teacher, mentioned, "Taiwanese parents think, 'Other children do it, so my child needs to do it.' They do not want their children to lose out to other children. They have that kind of thinking."

Many teachers and principals also pointed out that this current trend is a reflection of wishes the parents had when they were young. In past generations, because of the economic situation in the society, most parents couldn't afford to let their children learn about art, even if they were interested or had talent in the area. With the rapid economic developments in Taiwan, most Taiwanese parents have the financial ability to be able to afford sending their children to a variety of talent classes. Art talent class is one of them. In addition, the teachers pointed out that parents hope their children can learn to draw and gain art skills. In other words, Taiwanese parents hope their children can draw realistically, not abstractly, which they consider useless scribbling. For example, Mrs. Chang, a public kindergarten teacher and principal, stated:

For parents, the number one thing they want for their children if they send them to art class is for them to learn to draw things as they really look. They think that this is how they will get their money's worth from the art classes. ... That is, parents think, 'I am paying money, so if the teacher teaches you to draw a car, then you should know how. 
An art specialist and some teachers also explained that some parents are preparing their children to take the screen test for the gifted art classes in the elementary schools, especially in Taipei. Like Mrs. You, an art specialist, said, "I think in the Taipei area, some parents send their children to attend these classes because they hope their children will be chosen for a gifted art class in the future."

Perhaps these children do have some interest in art; however, parents have considerations beyond this. It is important to parents for their children to advance to higher levels of school, and participation in these gifted art classes offer a better chance for their children to enter college. Few children have success in both academics and art, so they will be more likely to pass the entrance exam for college. Thus, parents are more willing to follow their children's interests. However, it does not matter to the parents whether their children become artists in the future, only that they earn a college diploma, according to one art specialist, Mrs. You. She indicted:

Many parents who are in favor of their children attending the gifted art class also hope... Because if their children attend the gifted art classes, they will have a better chance to enter college. However, the pressure is much greater. Because if, in addition to art, the schools emphasize the academic subjects, they have a better chance to enter college in the future. There are still many students who attend the screening exam for entering the gifted art class. Thus, they tend to have more pressure.

Another reason pointed out by the teachers and principals was the inefficiency of art education in the private kindergarten. Since most of the children's time is devoted to cognitive learning, parents want their children to attend such classes after school to compensate for their lack of knowledge in the arts. Mrs. Young, a public kindergarten teacher and principal, stated:

Because I taught in the private kindergarten before, I do think they need extra art classes there. ... Why? Because when I was in the private kindergarten, I found that children spend their whole day learning knowledge related to the cognition areas--like cognition games, matching or others. They have almost no art activity.

In a related issue, parents are afraid that their children have not had previous art experiences, so they will not know how to draw when they enter elementary school. Mrs. Chang, a public kindergarten teacher as well as a principal, pointed out, "If I am a parent, I send my children to art class, and I hope that they will have a lot of experiences which will help them know how to draw later." Here again, parents' concept of "how to draw" is drawing something that is easily recognized.

Some teachers stated that other parents' reasons include fostering their children's hobby, exploring their children's potential, cultivating their children's minds or occupying their time. Or, most likely, the parents do not know how to teach their young children art, so they want the teachers to do it.

In past decades, parents in Taiwan have viewed academic achievement as most important for young children. Children should pay attention only to studying. Currently, this situation is changing, and parents have started to pay attention to other aspects of child development, such as art. Unfortunately, children's interests are still not the main consideration when parents make school decisions. Instead, they focus on the concerns 
previously mentioned. Should the educator view these changes as good or bad? And how should educators respond to these changes in education?

\section{Teachers' and Principal's Attitudes toward DAP Art Education--A Different Start}

Art educators are gradually making progress toward adopting the child-centered approach to teaching art in Taiwan (Chung, 1996). Unfortunately, according to my observations, currently in Taiwan most kindergarten teachers still adopt the traditional approach, or the teacher dominated approach, to teach art classes. In such a class, the children follow the teacher's directions to make art projects. Every child does the same work at the same time and most of the time the products of the children's work look exactly the same. In such classes, teachers use whole group instruction of young children because they feel it is necessary for control of the classroom with a large class size. This occurred in both the public and the private kindergartens.

Surprisingly, teachers in public kindergartens must care for nearly thirty children during art activities, even though each class has two head teachers. This is because the two head teachers take turns designing and guiding the art class each week, rather than working together during the art activities. Thus, in these classrooms, curriculum considerations such as following children's interests or abilities are often neglected. In addition, the teachers noted that young children have limited past experiences on which to draw, so the teachers need to direct them in creating art. Mrs. Young, a public kindergarten teacher and principal, indicated:

I prefer to leave children alone and let them make art by themselves. Ha! Ha! Ha! Ha! It is a way of totally free creation I like it the best. However, it involves the issue of man-power-the teachers' strength. ... The students need a lot of past experiences to build on, and then they can create, and I can leave them alone art with an activity.

During my observations for this study, all of the kindergarten teachers, except for one in the private kindergarten, adopted the teacher-directed approach to teach young kindergarteners about art. The procedure for the Taiwanese kindergarten art activities can best be described as follows: the teacher discusses with the children what they will do for the art class; the teacher demonstrates, before or after showing examples; the teacher distributes the materials; the teacher supervises while the children work; if used, the teacher facilitates a period of art appreciation after the children finish their work; the teacher and the children clean up, alone or together.

Some of the public kindergarten classrooms adopted a nonintervention approach in conjunction with the teacher-directed approach, depending on which art activity the teacher offered. Activities such as journal drawing in the pubic kindergartens are more likely to use a nonintervention approach. Most private kindergartens adopted the teacher directed approach; only one private kindergarten adopted the nonintervention approach of allowing children free choice in participating in activities. The art specialists in the private kindergartens also tended to use a teacher-directed art approach in kindergarten art teaching.

However, surprisingly, most kindergarten teachers expressed a preference toward the DAP art approach during their interviews. They recognized the importance of the 
teacher's role in teaching art. They thought that for kindergarteners the DAP art teaching approach was probably the best, and some teachers also expressed a preference for the nonintervention approach. However, they also pointed out concerns regarding the nonintervention approach in kindergarten due to the age of the children. They thought there should be stages of development, from teacher-directed to DAP to nonintervention approach, since the latter approach is very ideal but not as appropriate for children of this age.

Public teachers appeared to have more opportunities to teach developmentally appropriate curriculum than teachers in the private kindergarten art classrooms, because of the characteristics of the public kindergarten. Like teachers in the public classrooms pointed out, fortunately, writing and the Chinese phonetic symbols are not the regular curriculum topics for kindergarteners in their schools. Since they do not need to spend time teaching these subjects in their classrooms, teaching can be more normalized and can meet the six kindergarten education goals. In other words, children's time in school can be divided more equally among several kinds of learning, including art.

Unlike public kindergartens, teachers in private kindergartens must honor parents' requests in order to attract more children to attend their kindergartens. Therefore, it becomes more important for private kindergarten teachers to teach young children about writing, Chinese phonetic symbols and other cognitive skills in school, even though some of these subjects are not considered very appropriate for young kindergarteners to learn. Mrs. Lin, a public kindergarten teacher as well as principal, expressed her observations on the private kindergarten:

(D) uring the regular school day in kindergarten, what do the children learn?

They learn about cognition, writing, numbers, addition and subtraction, which should not be taught at the kindergarten level.

Another phenomenon was found regarding kindergarten art education in private schools in Taiwan. In addition to the regular classroom teachers, art specialists were hired from outside the private kindergartens to teach art. Two art specialists participated in this study. Based on the interviews and observations, the art specialists tended to adopt a more teacher-directed approach to teaching art to young kindergarteners. Mrs. Jian, an art specialist, indicated that she preferred to use the teacher-directed approach to teach young children art lesson because of their age, as well as difficulties in acquiring art materials in the classrooms, such as clay. She stated:

I think children at this young age probably do not have spontaneity. ... Like if they want to work, um, with clay, then they need to have clay and other tools.

But, they probably do not know how to get those materials. ... However, I do think the first (traditional) approach is more appropriate for young kindergarteners. Currently, I am supposed to use the first (traditional) approach, because to get the clay materials as well as to fire the clay, you must follow special procedures. It is impossible for us to allow children to take these home....

Mrs. You, an art specialist, also pointed out during the interview that because of the age of the children, they needed a teacher-assigned topic. She discussed her favorite approach for art teaching.

I think it depends on the children's ages. If they are just beginning to learn, I think they still need a topic to follow. I favor the first one (traditional approach). ... I think because some kindergarteners still cannot,... Um, some topics, they still 
have no way to express well, I think I still need to give them a topic. As for the rest of the work, I will allow them to create freely.

Moreover, the art specialists tended to emphasize skill development over creativity in their art classes. Mrs. Hu, a public kindergarten teacher, stated:

In fact, when I was teaching in the private kindergarten, I watched this kind of art class or talent class. I observed it a lot but I did not teach it myself. After I watched, my feeling was that children learn more in those art classes ... Um, I mean art skills. Right! They are learning art skills like matching colors, techniques for drawing or holding a pen. They learn these skills much better. However, as for their critical thinking skills, they seemed not to improve, but to stabilize.

In this approach, only very small variations in the children's artwork are encouraged in the art classrooms. The final goal of the art class for the art specialist is to allow the young children to acquire better art skills, probably because their training is in art and art is their profession, so they know more about art skills than the regular kindergarten teachers. However, when teaching such young children, they seem to neglect consideration of the children's developmental age and their need for freely expressing themselves through art.

\section{The Needed Changes-Teachers' Further Study and Student Numbers}

Almost all kindergarten teachers pointed out that the needed change in kindergarten art education is regarding teachers' further study and training. For example, one public kindergarten teacher, Mrs. Hu stated:

Teachers' self-improvement. I think it is very important to offer opportunities for teachers' further training and study. In fact, every teacher should have a concept of beauty or feeling about beauty. This kind of aesthetic education is necessary for every teacher, especially kindergarten teachers.

Most likely this is because most teachers did not major in art, so they think that progress in their art teaching is necessary. They may not feel confident about teaching art in their classrooms. Mrs. Lin, who is a teacher and principal at her school, stated:

(O)f course, we hope to have more opportunities for teachers' in-service training, and workshops which allow teachers to participate and enrich their own..., um, experiences, knowledge or even skills. Because we are not good at everything. Like myself, I am not very good at art. I think I do lack this kind of ability. I feel I cannot make anything. When I was teaching, in fact, I did not feel very confident. However, you need to teach it, so you need to gain a basic understanding about it, you need to find information about it and sometimes you need to see how other teachers teach it. ... So, I think there should be more opportunities for training and workshops - that teachers can participate in.

Another important needed change that kindergarten teachers pointed out is related to student numbers in the kindergarten classrooms. Currently, there are thirty children in one kindergarten classroom, based on regulations. Both public and private kindergarten teachers expressed similar concerns. This may be because even though there are two head teachers in the public kindergarten classrooms, the teachers take turns teaching and designing the curriculum, rather than working together. In other words, like the private 
kindergarten teachers, teachers in public schools also take care of thirty children during the art class. The student numbers in the classrooms are too high, especially during art class, when more children need the teacher's help. Mrs. Chang, who is a public kindergarten teacher and principal, stated:

For example, I think the student numbers are too high. I mentioned this before. That is, the teacher to student ratio. In addition, I think all kindergartens should be set up based on the children's interests. I think it is applicable. ... Moreover, I think it is important to have a special art classroom. The issue of space is important. Like, we have some very big easels and we have no place to put them. We put them outside for two days and still couldn't find a place to put them. We need more space. ... In addition, teachers need opportunities for training and further study. I think teachers' concepts for art teaching will improve. Among all of those, I think the student numbers should be reduced first. For one teacher, she cannot... It is very burdensome.

Another important change needed is in regard to the classroom environment, as some teachers feel dissatisfied about their classrooms during art activities, as Mrs. Chang, a public kindergarten teacher and principal, mentioned. Tables and chairs take up a lot of room in the classroom. The children's resting area is also in the classroom, which leaves very little space for the storage of children's artwork and art supplies. Clean up is another problem in such shared-function classrooms.

One public and one private kindergarten teacher each pointed out that the children need to have more opportunities for art appreciation and a complete curriculum in art, which no teacher expressed in the interviews. Mrs. Chen, the public kindergarten teacher and principal, indicated:

Probably, allow children to have more opportunities to go out and see artists' work. Um, like a painting exhibition. This kind of stuff. ... Kindergartens really should do it this way.

Unlike the kindergarten teachers, the art specialists did not consider that further study and training for teachers or reducing the student numbers to be necessary changes. Rather, one art specialist, Mrs. You, expressed that the parents request a perfect product from their children, so some teachers help children to do the work and some teachers use pre-drawn materials in art classes. She said:

I think some parents do not understand children's development, so they will ask their children to make things which are perfect or very beautiful. I think since there are several stages of children's art development... If the parents ask young children to make their work have some kind of likeness, I am not in favor of it. Because usually, the teachers substitute for the children doing the work, which then does not belong to the children. It is useless if the children bring these home.

\section{Conclusions}

Although teachers emphasize creativity, art appreciation, etc., observations in the classrooms generally showed a rigid teaching method. Teachers have a high degree of control in the classroom and offered few opportunities for free expression. Teachers found the ideas from the DAP approach for art education acceptable. Many of them stated that one of the areas that needed attention included teachers' additional study and 
training. Although it is likely that difficulties will be encountered while carrying out DAP in Taiwanese art classrooms, there is hope that schools will work to give young children in Taiwan a higher quality program of early childhood art education.

\section{References}

Beittel, K. R. (1972). Mind and Context in the Art of Drawing. New Youk: Holt, Rinehart and Wiston.

Beittel, K. R. (1973). Alternatives for Art Education Research. Dubuque, IA:

Willima C. Brown.

Bredekamp, S. \& Copple, C, (Eds.) (1998). Developmentally Appropriate

Practice in Early Childhood Programs. Washington, DC: National Association for the Education of Young Children.

Davis, J. (1997). The "U" and the Wheel of "C": Development and Devaluation of Graphic Symbolization and the Cognitive Approach at Harvard Project Zero. In A. M. Kindler (Ed.), Child Development in Art, (pp. 45-58). Reston, VA: The National Art Education Association.

Duncum, P. (1997). Subjects and Themes in Children's Unsolicited Drawing and Gender Socialization. In A. M. Kindler (Ed.), Child Development in Art, (pp. 107-114).

Reston, VA: The National Art Education Association.

Golomb, C. (1997). Representational Concepts in Clay: The Development of

Sculpture. In A.M. Kindler (Ed.), Child Development in Art, (pp. 131-142). Reston, VA: The National Art Education Association.

Kellogg, R. (1970). Analyzing Children's Art. Mountain View, CA: Mayfield Publishing Company.

Kinder, A.M. (1995). In Thompson, C.M. (Ed.), The Visual Arts and Early Childhood Learning, (pp.10-14). Reston, VA: The National Art Education Association.

Lasky, L. \& Mukerji-Bergeson, R. (Eds.) (1995). Art: Basic for Young Children. Washington, DC: National Association for the Education of Young Children.

Lowenfeld, V.\& Brittain, W.L. (1987). The Creative and Mental Growth. Upper

Saddle River, NJ: Prentice Hall.

Piaget, J. (1952). The Origins of Intelligences in Children. New York:

International University Press.

Thompson, C. M. (1995). In Thompson, C.M. (Eds.), The Visual Arts and Early Childhood Learning, (pp.1-5). Reston, VA: The National Art Education Association.

Thunder-McGuire, S. (1994). An Inner Critic in Children's Artistic Bookmaking. Visual Arts Research,20(2),51-61.

Vygotsky, L. S. (1978). Minds in Society. M. Cole, V. John-Steiner, S. Scribner, \& E. Souberman, (Eds. \& Trans.). Cambridge, MA: Harvard University Press.

Wilson, M \& Wilson, B. (1982). Teaching Children to Draw: A Guide for Teachers and

Parents. Englewood Cliffs, NJ: Prentice-Hall Inc.

Zurmuehlen, M. (1990). Studio Art: Praxis, Symbol, Presence. Reston, VA: The National Art Education Association.

Zurmuehlen, M. \& Kantner, L. (1995). In Thompson, C.M. (Ed.), The Visual Arts and Early Childhood Learning, (pp.6-9). Reston, VA: The National Art Education Association. 